\title{
Legalitas Ucapan Selamat Natal Bagi Umat Islam Studi Kritis Terhadap Pemikiran Quraish Shihab Dalam Tafsir Al-Misbah
}

\author{
Mohammad Ruslan \\ fazaruslan61@gmail.com \\ IAI AL-Khairat Pamekasan
}

\begin{abstract}
Legality Derived from the word "legal" which means legal, valid according to law. While legality itself is legitimacy, legality. So "Legality" can be interpreted as a legitimacy or validity of a law based on State Law or the ideological source of a group. M. Quraish Shihab's interpretation process in legalizing the "Merry Christmas" greeting using QS. Maryam 33 through several methods including, using "Dalalah Lafadz 'Am, Syaddud dzaraI', and the rules of Maqashidul Lafdzi fiqh 'Ala Niatil Lafidz". With the latter method he interprets who is allowed or not to say "Merry Christmas". Like other contemporary commentators in interpreting the Qur'an, he also considers harmony and harmony between religious communities. None of the classical and contemporary scholars have stated that it is permissible to say "Merry Christmas" by saying that it has been approved by Al-Qur'an. The Qur'an is even recommended using the QS argument. Maryam verse 33 as used by M. Quraish Shihab in legalizing the saying. Ulama' who allow it only consider this as a form of "Mujamalah and Muhasanah" only. Because it is seen from the interpretation of the verse that none of the scholars interprets that the verse is a verse that approves the greeting of Merry Christmas, and also by looking at the history of the "Christmas" celebration.
\end{abstract}

\section{Keywords: Legality, Merry Christmas, Muslim}

Abstrak: Legalitas Berasal dari kata "legal" yang artinya sah, absah menurut hukum. Sedangkan legalitas sendiri adalah keabsahan, kelegalan. Jadi "Legalitas" bisa diartikan adalah sebuah keabsahan atau sah nya sebuah hokum yang didasarkan pada Undang-Undang Negara atau sumber ideologi suatu golongan. Proses interpretasi M. Quraish Shihab dalam melegalkan ucapan "Selamat Natal" dengan menggunakan QS. Maryam 33 melalui beberapa metode diantaranya, menggunakan "Dalalah Lafadz 'Am, Syaddud dzaraI', dan kaidah fikih Maqashidul Lafdzi 'Ala Niatil Lafidz'. Dengan metode yang terakhir beliau mentafshil siapa yang diperbolehkan atau tidak 
mengucapkan "Selamat Natal". Sebagaimana para mufassir kontemporer yang lain dalam menafsirkan Al-Qur an, beliau juga mempertimbangkan keharmonisan dan kerukunan antar umat beragama.Tak satupun ulama' klasik dan kontemporer yang menyatakan bahwa mengucapkan "Selamat Natal" itu boleh dengan mengatakan bahwa hal tersebut sudah direstui olah Al-Qur an bahkan dianjurkan dengan menggunakan dalil QS. Maryam ayat 33 sebagaimana yang digunakan M. Quraish Shihab dalam melegalkan ucapan tersebut. Ulama' yang memperbolehkan hanya menganggap hal tersebut sebagai bentuk "Mujamalah dan Muhasanah" semata. Karena memang dilihat dari penafsiran ayat tersebut tidak ada satupun ulama' yang menafsirkan bahwa ayat tersebut merupakan ayat yang merestui ucapan Selamat Natal, dan juga dengan melihat sejarah perayaaan "Natal".

\section{Kata Kunci: Legalitas, selamat natal, Muslim}

\section{Prolog}

Setiap masing-masing agama memiliki hari besar keagamaan yang berbeda antar satu sama lain. Seperti agama Islam yang memiliki dua hari raya dalam dalam setiap tahunnya yakni Hari Raya Idul Fitri dan Idul Adha. Budha mempunyai hari raya Imlek setiap tahunnya. Begitu pula dalam agama Kristen terdapat perayaan hari besar yang disebut dengan "Hari Natal" yang dilaksanakan pada pekan terakhir setiap bulan Desember tanggal 25 dan berdekatan dengan tahun baru masehi. Perayaan natal bermula dari upacara adat istiadat masyarakat penyembah berhala di daerah Mesir sebelum masuk Kristen, yakni setiap bulan Januari yang kemudian mereka jadikan sebagai hari kelahiran Yesus. Dan perayaan ini masuk pertama kali kedalam Kristen Katolik Roma pada abad keempat. Kebiasaan tersebut sulit dihilangkan, sampai mereka memeluk agama Kristen baik Protestan maupun Katolik. ${ }^{1}$ Berbeda dengan waktu perayaan Natal yang biasanya berlangsung pada bulan Desember tanggal 25, hal tersebut dipengaruhi oleh kepercayaan kafir Brumalia yang menganggap bahwa peletakan tanggal tersebut sebagai kelanjutan dari perayaan Saturnalia yang biasa dilaksanakan pada tanggal 17-24 Desember, dan perayaan menjelang akhir tahun serta perayaan menyambut matahari

\footnotetext{
${ }^{1}$ Herbert W. Amstrong, “Asal-Usul Perayaan Natal”, (Masyhud SM, Penerjemah), (t. t : t. p, T.th), 03 .
} 
baru. Dan kemudian kepercayaan tersebut diambil dan dilestarikan oleh Kristen walaupun secara praktek tidak 100 persen sama. ${ }^{2}$

Setiap perayaan hari besar keagamaan biasanya diramaikan dengan poster-poster di tempat umum seperti halnya di jalan raya, mall, dan lain sebagainya yang memang sengaja dipasang untuk memeriahkan perayaan hari besar tersebut.tak hanya itu, banyak para pemimpin negeri yang sengaja ikut andil dalam memeriahkan perayaan hari besar keagamaan dengan mengucapkan "Selamat" akan perayaan hari besar keagamaan tersebut. Dan juga masyarakat umum yang juga melakukan hal demikian terhadap teman, tatangga maupun rekan kerja yang sedang merayakan hari besar keagamaan tersebut, baik yang seagama maupun tidak. Sepertihalnya di Indonesia yang dihuni oleh masyarakat yang menganut agama yang beragam namun mereka bersatu dengan Ke-Bhinnekaan Tunggal Ika yang merupakan semboyan Indonesia, sikap tersebut mereka anggap sebagai bentuk toleransi agama untuk mencapai kerukunan antar umat beragama. Karena mereka hidup bersama dalam satu Negara dan sama-sama berjuang untuk memenuhi kebutuhan hidupnya yang direalisasikan dengan berbagai macam aktifitas serta berbagai macam hubungan antar sesamanya. Oleh karena itu, setiap pribadi selalu berada dalam keterikatan dan keterlibatan secara terus menerus sehingga tidak ada yang mempunyai kebebasan mutlak. tanpa kebersamaan manusia tidak mampu hidup sendiri sebagaimana fungsi manusia sebagai makhluk sosial atau yang oleh Aristoteles biasa disebut "Zoon politicon". 3

Umat Islam diberi kebebasan untuk menjalin sebuah hubungan social yang baik dengan siapapun termasuk dengan non-muslim sekalipun, sepertihalnya dalam masalah mu'a>malah baik dalam praktek jual beli atau bentuk Muamalah lainnya. Seperti dikisahkan dalam kitab Al-S\}irat Al-Nabawiyah, bahwa Nabi Muhammad SAW menyambut dengan hangat kunjungan 60 orang tokoh Nasrani Najran. Ketika rombonngan tersebut sampai di madinah, mereka langsung menuju masjid. Sedang saat itu nabi Muhammad SAW melaksanakan sholat ashar berjemaah. Mereka datang dengan memakai jubah dan serban. Ketika waktu kebaktian tiba, mereka tidak perlu mencari gereja. Nabi SAW memperkenankan menjalankan kebaktian dalam masjid. Itulah bukti bahwa kita diberi kebebasan bahkan dianjurkan

\footnotetext{
${ }^{2}$ Ibid., 7.

${ }^{3}$ Said Agil Husni, Fikih Hubungan Antar Agama. (Jakarta: Ciputat Press, 2003), 1.
} 
untuk menjalani hubungan social antar umat beragama dengan baik, seperti apa yang dicontohkan oleh teladan umat yakni Nabi Muhammad SAW, Beliau juga menunjukan bahwa Islam adalah agama yang toleran. sebagaimana firman Allah SWT :

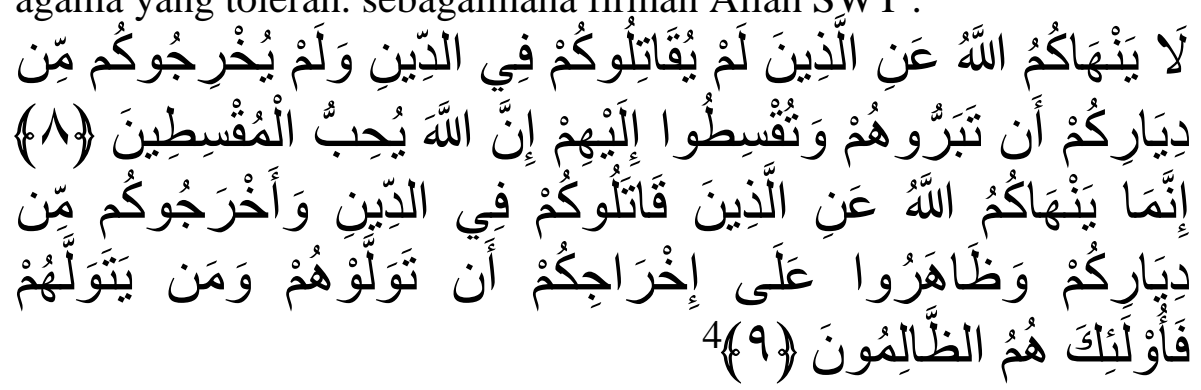

"Allah tiada melarang kamu untuk berbuat baik dan berlaku adil terhadap orang-orang yang tiada memerangimu karena agama dan tidak (pula) mengusir kamu dari negerimu. Sesungguhnya, Allah menyukai orang-orang yang berlaku adil (8). Sesungguhnya, Allah hanya melarang kamu menjadikan sebagai kawanmu orang-orang yang memerangi kamu karena agama dan mengusir kamu dari negerimu dan membantu (orang lain) untuk mengusirmu. Dan barang siapa yang menjadikan mereka sebagai kawan, mereka itulah orangorang yang lalim (9)."

Islam memang tidak pernah melarang umatnya berhubungan dengan siapapun, tetapi Islam tetap memberikan sekat pembatas dan tata cara umat islam melakukan interaksi social dengan mereka yang muslim maupun non-muslim. Dalam konteks sekat pembatas dalam berinteraksi sosial yang terjadi antara muslim dan non-muslim adala bertujuan untuk untuk melindungi akidah umat Islam sepertihalnya larangan berbaur dengan acara keagamaan mereka yang non-muslim.

Dalam berinteraksi sosial, manusia harus bisa membedakan antara moral universal seperti halnya kejujuran dan aturan moral yang khusus seperti halnya larangan memakan babi. Kemudian, dogmadogma dan doktrin-doktrin agama (yakni sisi moral) harus dipisahkan dari prinsip-prinsp dan aturan hokum. Dengan ini ia mengusulkan prinsip pemisahan hukum dari agama (moral). ${ }^{5}$

Fenomena yang terjadi dilapangan banyak masyarakat bahkan umaro' sekalipun yang turut memeriahkan acara keagamaan non-islam terutama agama Kristen Protestan dan Katolik yang keduanya

${ }^{4}$ Al-Qur'an, (Al-Mumtahanah: 60), 8.

5 Yudhie R. Haryono, May Rachmawatie, Al-Qur'an Buku Yang Menyesatkan Dan Buku Yang Mencerahkan (Jakarta: Gugus Press 2002), 193-194 
merupakan agama terbesar di Indonesia setelah islam. keduanya memiliki kegiatan keagamaan yang semuanya hampir sama, dan juga dengan hari raya yang sama yaitu "Natal". ${ }^{6}$ Karena mereka beranggapan bahwa dengan cara inilah mereka bisa membuktikan bahwa Islam merupakan agama yang toleran dan dengan itulah terjalin kerukunan antar umat beragama. Hal inilah yang menimbulkan polemik di kalangan tokoh agama yang sebagian dari mereka (tokoh agama) meng-ilegalkan umat islam turut andil dalam perayaan hari besar keagamaan walaupun hanya dengan ucapan "selamat natal". Seperti halnya pernyataan Syaikh Ibnu 'Uthaimin bahwasannya :

"Memberi Ucapan Selamat Natal" atau hari-hari besar lainnya bagi seorang muslim adalah haram menurut kesepakatan ulama'. Sebagaimana hal itu telah disampaikan oleh Ibnu Al-Qayyim rahimahullah dalam kitabnya "Ahkamu Ahl Al-Dhimmah". Hal tersebut dianggap sama halnya memberi selamat kepadanya atas tindakannya bersujud kepada salib, bahkan hal itu lebih besar dosanya kepada Allah daripada memberikan ucapan selamat karena meminum minuman keras, membunuh, berzina dan lain-lain. Dengan demikian, barang siapa memberi ucapan selamat kepada seseorang atas kemaksiatan, bid'ah atau kekufuran, maka ia telah menjerumuskan dirinya terhadap kekufuran dan murka Allah". 7

Allah SWT tidak meridlai kekufuran atau simbol dari kekufuran. Sebagaimana firman Allah SWT:

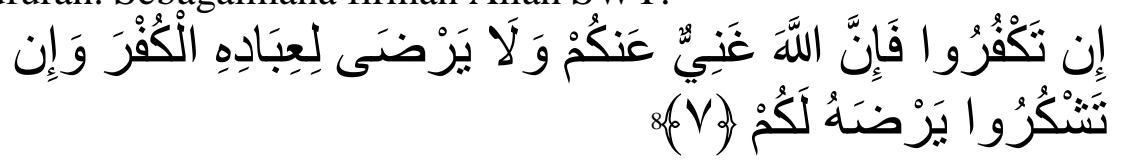

"Jika kamu kafir maka sesungguhnya Allah tidak memerlukan (iman)mu dan Dia tidak meridhai kekafiran bagi hamba-Nya; dan jika kamu bersyukur, niscaya Dia meridhai bagimu kesyukuranmu itu”.

Berkenaan dengan ucapan "Selamat Natal", Salah satu pakar tafsir kontemporer indonesia "Prof. Dr. Muhammad Quraish Shihab M.A." yang sampai saat ini masih eksis dan banyak berkecimpung dalam bidang penafsiran al-qur'an memiliki sudut pandang yang berbeda dari sebagian ulama' yang meng-Ilegalkan ucapan tersebut,

\footnotetext{
6 Tony Chandra, "perbedaan katolik dan protestan", dalam Http;//www.kaskus,co.id/artikel (05 November 2015).

${ }^{7}$ Sulaiman Bin Shalih Al-Khurasyi: Pemikiran Dr. Yusuf Al-Qardhawi Dalam

Timbangan, (M. Abdul Ghaffar, Penerjemah). (Bogor: Pustaka Imam Syafi'i, 2003), 242

${ }^{8}$ Al-Qur'an, (Al-Zumar: 39), 7.
} 
sehingga masih terjadi ikhtilaf antar ulama' baik dikalangan Fuqoha' atau Mufassirin. Namun, Quraish Sihab mempunyai alasan dan dalih yang kuat dengan berlandaskan al-qur'an sebagaimana terdapat dalam kitab "Tafsir Al-Misbah" . dan masih banyak ide dan gagasan yang beliau tuangkan dalam bentuk tulisan dan tak jarang gagasan beliau bersifat kontroversial.

\section{Pendapat Ulama Mengenai Ucapan Selamat Natal}

1. Legalitas Ucapan Selamat Natal Menurut Ulama Klasik

Mayoritas ulama' klasik mengharamkan ucapan selamat natal dengan berbagaim macam alasan. Diantara pendapat-pendapat tersebut adalah sebagaimana berikut:

a) Imam Khatib As-Syarbini dalam kitabnya Mughni Al-Muhtaj Fi Alfazh Al-Minhaj, dalam kitab tersebut beliau menjelaskan bahwa mereka yang mengikuti orang-orang kafir dalam merayakan hari raya mereka harus ditakzir. meskipun hanya sekedar ucapan selamat natal, meskipun ucapan selamat natal tersebut diutarakan kepada mereka yang status kekafirannya merupakan Kafir Dzimmi. ${ }^{9}$ Secara tidak langsung beliau melarang terhadap ucapan selamat natal tersebut.

b) Menurut Ibnu Al-Qoyyim Al-Jauzi tidak boleh hukumnya bagi seorang muslim memiliki kecendrungan terhadap non-muslim, membentu atau hadir bersama mereka diacara keagamaan mereka, hal ini didasarkan kesepakan $\mathrm{Ahl} A \mathrm{Al}$-'Ilm. Dan telah dijelaskan oleh para fuqoha' yang merupakan pengikut Al-Aimmatu AlArba'ah dalam kitab-kitab mereka. Sepertihalnya yang dikatakan Abu Al-Qo>sim Hibbatullahi Bin Al-Hasan Bin Manshur AtThobariy Al-Faqih Al-Syafi'iey, bahwa seorang muslim tidak boleh menghadiri acara keagamaan non muslim dengan alasan hal tersebut merupakan perbuatan munkar dan sebuah keburukan. Dan ketika ada orang muslim berbaur dalam acara tersebut tanpa ada pengingkaran dalam hati mereka terhadap acara tersebut berarti mereka sama halnya meridhai terhadap acara tersebut (kekufuran). Dan nantinya akan menyebabkan murka Allah, Na'udzubillahi Min Dzalik. ${ }^{10}$

\footnotetext{
${ }^{9}$ Imam Khatib As-Syarbini, Mughni> Al-Muhtaj, jld: 06 (T.Tp: T.P, T.T), 526.

${ }^{10}$ Syaikh Muhammad Bin Abi> Bakr Ibnu Qoyyim Al-Jauzi, Ahkam Ahl Ad-

Dzimmah, jld: 01, ( Saudi Arabia: Romadi Li An-nasyr, 1997) 1245.
} 
Sedangkan untuk pengucapan tahniah (selamat) terhadap syi'ar-syi'ar kekufuran yang khusus untuk orang kafir hukumnya haram menurut kesepakatan ulama'. Dan termasuk kedalam kategori syi'ar agama adalah hari raya. ${ }^{11}$ Sepertihalnya mengucapkan selamat pada hari raya dan puasa mereka seperti mengatakan: "semoga hari raya ini menjadi hari yang berkah bagimu", atau walalupun hanya sekedar mengatakan "selamat pada hari raya ini", atau saat ini yang biasa kita kenal dengan ucapan "Selamat Natal" atau "Marry Critsmass", hal tersebut hukumnya haram. Sebab ucapan tersebut di anggap setara dengan ucapan selamat atas sujud yang mereka lakukan terhadap salib. dan dosanya lebih besar dari orang yang meminum minuman keras, berzina, bahkan membunuh sekalipun. ${ }^{12}$

Melihat alasan Ibnu Qoyyim sebelumnya mengenai keharaman menhadiri hari raya Non-Islam berlaku ketika tidak ada pengingkaran dalam hati mereka terhadap ajaran tersebut. sehingga bisa dikatakan, bahwa ketika seseorang menghadiri acara tersebut namun dalam keadaan hati yang mengingkari tehadap ajaran tersebut maka keharaman itu tidak berlaku. Apalagi dalam masalah ucapan selamat hari raya, ketika dianalogikakan dengan menghadiri acara, maka lebih besar 'illat yang terkandung dalam menghadiri acara dari pada hanya sebuah ucapan yang juga disertai dengan pengingkaran terhadap momen tersebut. sehingga pemberlakuan hukum yang ada pada menghadiri acara bisa diaplikasikan terhadap legalitasnya ucapan selamat hari raya Non-islam.

c) Syaikh Muhyiddin An-Nawawiy berpendapat bahwa sudah selayaknya bahkan wajib seorang muslim bungkam atau tidak ikut serta dalam menyiarkan perkara munkar. Sepertihalnya memperdengarkan umat islam pada kesyirikan mereka, sepertihalnya kepercayaan mereka terhadap ketuhanan 'Isadan 'Uzair, meminum khomr, dan juga turut serta dalam menyiarkan hari raya yang khusus pada mereka. Sepertihalnya mengatakan "Selamat Natal". 13

d) Syaikhul Islam Imam Zakariya , pendapat beliau tidak jauh beda dengan pendapat sebelumnya, bahwa wajib bagi setiap muslim

\footnotetext{
${ }^{11}$ Muhammad nashir ahmad as-syafi' iey al-mali>bari, Rad'u Al-Aghwad 'An Muwalati Al-Kuffari Wa At-Tasyabbuhi Bihim Wa Tahniatihim Bi Al-A'yad, (Indonesia: menara ahli sunnah, 2018), 13

${ }^{12}$ Syaikh Muhammad Bin Abi Bakr Ibnu Qoyyim Al-Jauzi, Ahkamu , Jld:

01, 441-442.

${ }^{13}$ Muhyiddin An-Nawawiy, Ar-Raudlah, Jld: 10,(T.Tp: T.p, T.Th), 328.
} 
untuk tidak menyiarkan/melakukan perkara munkar secara terangterangan diantara orang muslim, sepertihalnya memperdengarkan sebuah perkataan kepada kita mengenai tuhan trinitas, meminum khamr dan memakan bangkai secara terang-terangan, menyiarkan hari raya mereka (Non-muslim) termasuk mengucapkan selamat, dengan alasan hal tersebut termasuk menyiarkan syi'ar-syi'ar kekufuran. ${ }^{14}$

e) Sedangkan menurut Imam Ibrohim Al-Bajuriy, yang merupakan guru besar Univeritas Al-Azhar pada tahun $1276 \mathrm{H}$. pendapat beliau juga sama dengan pendapat-pendapat sebelumnya yang melarang ucapan "selamat natal". Beliau menuturkan dalam kitabnya Hasyiah Al-Bajuriy bahwa "seorang muslim dilarang meminum khomr, memakan daging babi, menyampaikan secara terang-terangan mengenai hari raya Non-Muslim,"15

f) Syaikh Manshur Bin Yunus Al-Bahutiy, yang hidup pada tahun $1051 \mathrm{H}$ dan termasuk Imam bermadzhab Hanbali. Beliau memiliki pendapat yang sama dengan ulama-ulama sebelumnya walaupun mereka bermadzhab syafi'ie. Menurut beliau "umat islam dilarang melakukan secara terang-terangan hal-hal munkar sepertihalnya menyampaikan secara terang-terangan (menyiarkan) hari raya Non-Islam, atau penyembahan terhadap berhala". ${ }^{16}$

g) Ibnu Taimiyah berpendapat bahwa ikut serta umat islam pada orang kafir dihari raya mereka dalam bentuk apapun hukumnya haram mutlak. Baik itu berupa ucapan selamat hari raya dan semacamnya yang termasuk ikut serta dalam perayaan hari raya keagamaan mereka. ${ }^{17}$ menurut beliau hari raya merupakan sebagian dari ajaran sebuah agama, manhaj, dan bentuk ibadah dari suatu agama. Sebagaimana firman Allah SWT dalam QS. AlHajj ayat 67:

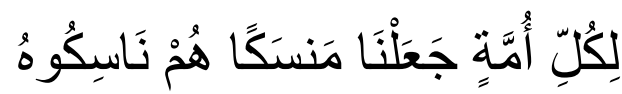

"Bagi tiap-tiap umat telah Kami tetapkan syari'at tertentu yang mereka lakukan"

\footnotetext{
${ }^{14}$ Syaikhul Islam Zakariya Al-Anshoriy, Syarh Al-Manhaj, Jld: 04, (Mesir: Mustofa Al-Babi Al-Halabi, 1345), 274.

${ }^{15}$ Imam abrahim al-bajuriy, Hasyiah Al-Bajuriy 'ala Syarh Ibnu Qasim Al-Ghazi

'Ala Matni Al-Ghayah, jld: 04, (Jeddah: Dar Al-Minhaj, 2016), 305.

${ }^{16}$ Syaikh Manshur Bin Yunus Bin Idris Al-Bahutiy Al-Hanbali, Kassyafu Al-Qona'

'An Matni Li Al-Iqna' Li Al-Bahutiy, (Riyadh: Dar 'Alam Al-Kutub, 2003), 1364.

17 Muhammad Nashir Ahmad As-syafi'ie Al-Malibari, Rad'u Al-Aghwad.........20
} 
Perayaan Hari raya sama halnya dengan ibadah yang lain, seperti halnya puasa, sholat, haji, dan sebagainya. Maka tidak ada bedanya ketika umat islam ikut serta dalam hari raya mereka dengan ikut serta dalam bentuk ibadah mereka yang lain. Sehingga ketika ada umat islam ikut serta dalam perayaan hari raya Non-Islam, berarti dia sepakat terhadap kekufuran dan juga sepakat terhadap budaya-budaya orang kafir, seperti menyembah berhala dan semacamnya.

Menurut beliau hari raya merupakan sebuah momen istimewa yang berbeda dari ajaran-ajaran lainnya. dan sebuah pengaplikasian yang paling jelas dari sebuah ajaran agama, sehingga ketika ada seorang muslim yang sepakat atau ikut andil dalam perayaan hari raya Non-Islam maka mereka turut serta dalam pelaksanaan ajaran teristimewa orang kafir dan turut serta dalam menyiarkan syariat NonIslam. $^{18}$

1) Menurut Syaikh Ibnu Utsaimin memberi ucapan selamat hari natal atau hari-hari besar lainnya kepada orang-orang kafir haram. Hal tersebut di nuqil dari pendapat Ibnul Qayyim Rahimakumullah dalam kitabnya, Ahkamu Ahli Ad-Dzimmah. Bahkan dengan ekstremnya, beliau berpendapat bahwa mengucapkan selamat natal lebih besar dosanya dihadapan allah daripada memberi ucapan selamat karena meminum minuman keras, membunuh seseorang, berzina dan lain-lainnya. dan banyak orang yang melakukan hal tersebut tanpa mengetahui buruknya pekerjaan tersebut. keharaman tersebut juga dikarenakan dianggap bahwasannya di dalamnya terkandung pengakuan terhadap simbol-simbol kekufuran. Atau memberikan selamat atasnya. ${ }^{19}$ Sebab allah swt tidak meridlai hal tersebut, sebagaimana firman allah:

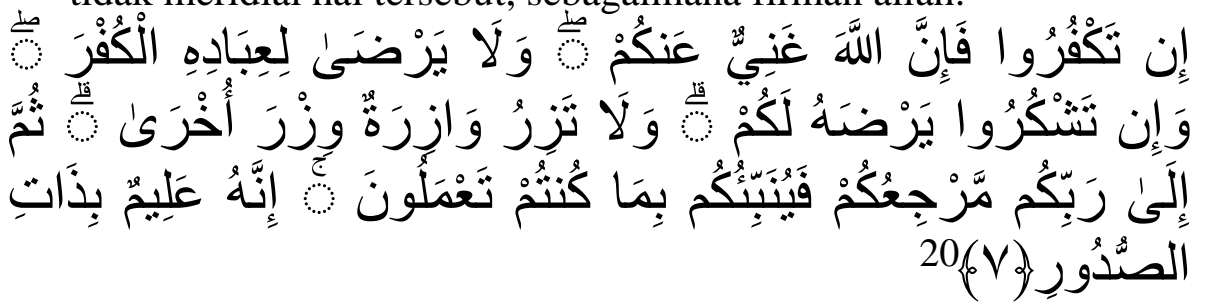

"Jika kamu kafir maka sesungguhnya Allah tidak memerlukan (iman)mu dan Dia tidak meridhai kekafiran bagi hamba-Nya; dan jika kamu bersyukur, niscaya Dia meridhai bagimu kesyukuranmu itu; dan

\footnotetext{
${ }^{18}$ Syaikh Ahmad Bin Abdul Halim Bin Abdus Sala>m Ibnu Taimiyah, Iqtidhau AlShiratha Al-Mustaqim, (t.t: Mathba'ah Syarfiyyah, 1907), 98-99

${ }^{19}$ Sulaiman Al-Khuraisyi, "Pemikiran Dr. Yusuf Al-Qardlawi....

${ }^{20}$ Al-Qur a>n, (Az-Zumar:39), 7. $.242-243$
} 
seorang yang berdosa tidak akan memikul dosa orang lain. Kemudian kepada Tuhanmulah kembalimu lalu Dia memberitakan kepadamu apa yang telah kamu kerjakan. Sesungguhnya Dia Maha Mengetahui apa yang tersimpan dalam (dada)mu”.

a. Legalitas Ucapan Selamat Natal Menurut Ulama Kontemporer

Ada beberapa fatwa ulama' kontemporer mengenai ucapan selamat natal diantaranya:

1) Menurut syaikh wahbah zuhaili, tidak ada halangan dalam bersopan santun (Mujamalah) dengan orang nasrani. Yang mana menurut sebagian ahli fikih berkenaan berkenaan dengan hari raya nasrani, hal tersebut tidak dimaksudkan sebagai pengakuan atas (kebenaran) ideology mereka. ${ }^{21}$

2) Syaikh Musthafa Zarqa seorang ulama fikih dari Suriah berpendapat bahwa "ucapan selamat natal" seorang muslim pada temannya yang nasrani adalah bentuk sopan santun (Mujamalah) dan berbaikan dalam pergaulan (Muhasanah). Islam tidak melarang umatnya untuk bersopan santun dan berbuat baik kepada mereka dan tidak ada dalil yang secara tegas melarang ucapan tersebut. sedangkan pembolehan tersebut didasarkan pada firman Allah SWT QS. Al-Mumtahanah ayat 8 yang maksudnya Allag tidak melarang muslim untuk berbuat baik kepada mereka Non-Muslim yang tidak memerangi Muslim. hanya saja mereka menganggap nabi isa yang statusnya sebagai nabi dalam islam dianggap sebagai tuhan. Hal tersebut adalah hal yang sangat berlebihan. ${ }^{22}$

3) Syaikh Yusuf Al-Qardhawi, hukum mengucapkan "Selamat Natal" boleh, hal tersebut dianggap sebagai perbuatan baik kepada sesama. Terlebih apalagi ada hubungan emosional dengan mereka seperti kerabat, tetangga, rekan bisnis, atau teman sekolah.Dengan catatan, mereka yang merayakan Natal tidak sedang memerangi muslim. Hal tersebut dengan mempertimbangkan situasi dan kondisi. ${ }^{23}$

4) Menunurut fatwa majelis ulama Eropa, "tidak ada larangan bagi individu muslim atau organisasi islam untuk mengucapkan selamat natal secara lisan atau dengan kartu yang tidak mengandung syiar

\footnotetext{
21 "Dalil Dan Argumen Mengucapkan Selamat Natal Menurut Para Ulama' Dunia”, dalam https://dutaislam.com/artikel/Fikih/Litera (25 Desember 2017)

22 Ahmad Sarwat, "Hukum Mengucapkan Ucapan Selamat Natal", dalam https://rumahfiqih.com/artikel, 25 Desember 2012

${ }^{23}{ }^{23}$ Nasih Nasrullah, "Beda Syaikh Yusuf Al-Qardhawi, Mesir, Dan Saudi Soal Natal”, dalam https://republika.co.id/Berita/Fatwa/Khazanah Islam (25 Desember 2017)
} 
atau ucapan keagamaan yang berlawanan dengan prinsip islam. Kalimat yang digunakan hendaknya tidak mengandung pengakuan apapun atas agama mereka dan rela atasnya. Melainkan hanya berupa kalimat mujamalah (sopan santun) yang umum dikenal.

5) Menurut Syaikh Ali Jum'ah yang merupakan mufti Mesir sekaligus pimpinan Da>r Al-Ifta' pada tahun 2008 menyatakan bahwa boleh hukumnya mengucapkan "Selamat Natal" karena hal tersebut dianggap sebagai bentuk interaksi sosial dan hadiah. Beliau juga berpendapat bahwa perlakuan baik terhadap sesame sangat ditekankan dalam Al-Qur a>n di beberapa Ayat seperti yang tertuang dalam firman Allah SWT sebagaimana berikut: ${ }^{24}$

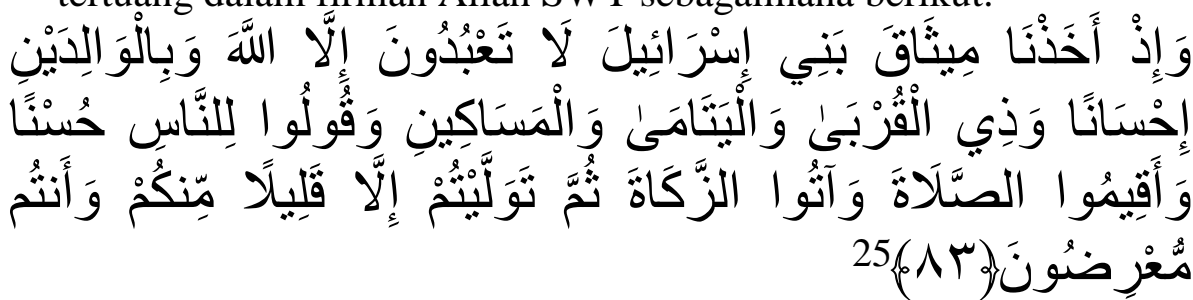

"Dan (ingatlah), ketika Kami mengambil janji dari Bani Israil (yaitu): Janganlah kamu menyembah selain Allah, dan berbuat kebaikanlah kepada ibu bapa, kaum kerabat, anak-anak yatim, dan orang-orang miskin, serta ucapkanlah kata-kata yang baik kepada manusia, dirikanlah shalat dan tunaikanlah zakat. Kemudian kamu tidak memenuhi janji itu, kecuali sebahagian kecil daripada kamu, dan kamu selalu berpaling."

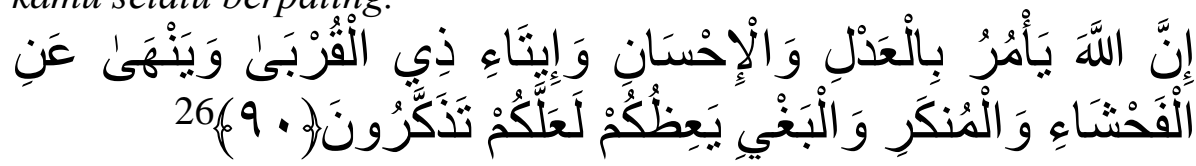

"Sesungguhnya Allah menyuruh (kamu) berlaku adil dan berbuat kebajikan, memberi kepada kaum kerabat, dan Allah melarang dari perbuatan keji, kemungkaran dan permusuhan. Dia memberi pengajaran kepadamu agar kamu dapat mengambil pelajaran."

\footnotetext{
${ }^{24}$ Nasih Nasrullah, "Beda Syaikh Yusuf Al-Qardhawi, Mesir, Dan Saudi Soal Natal”, dalam https://republika.co.id/Berita/Fatwa/Khazanah Islam (25 Desember 2017)

${ }^{25}$ Al-Qur an, (Al-Baqoroh: 02), 83

${ }^{26}$ Al-Qur an, (An-Nahl: 16), 90.
} 


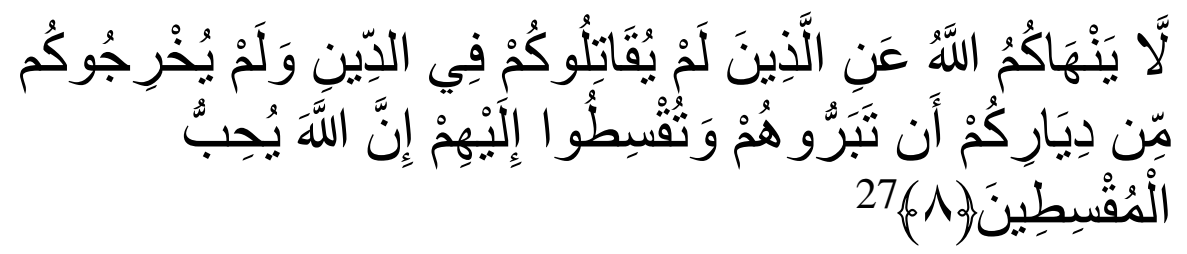

"Allah tidak melarang kamu untuk berbuat baik dan berlaku adil terhadap orang-orang yang tiada memerangimu karena agama dan tidak (pula) mengusir kamu dari negerimu. Sesungguhnya Allah menyukai orang-orang yang berlaku adil."

6) Menurut Syaikh Rasyid Ridha, dalah seorang pakar tafsir dari Mesir, sekaligus penyusun kitab "Tafsir Al-Manar" menyatakan bahwa hukum mengucapkan selamat natal boleh. Karena dialamnya terdapat kemaslahatan, yakni membentuk keharmonisan satu sama lain yang akan berujung pada kemaslahatan bangsa. Dan ketika keburukan bergaul dikaitkan dengan agama maka akan memperburuk reputasi agama. Sehingga boleh hukumnya seorang muslim mengunjungi seorang Nasrani pada hari perayaan agama mereka dan memperlakukan mereka dengan baik lebih baik dari cara memperlakukannya mereka terhadap Muslim dengan niat baik tanpa menyentuh ideology masing-masing. ${ }^{28}$

\section{Legalitas Ucapan Selamat Natal Dalam Tafsir Al-Misbah Qs. Maryam: 33.}

QS. Maryam ayat 33 merupakan ayat yang dijadikan dalil oleh M. Quraish Shihab sebagai pelegalan ucapan "Selamat Natal". Dan sepertinya beliau menggunakan beberapa metode dalam menetapkan hukum tersebut, diantaranya:

a. Menggunakan Fungsi Dalalah Lafadz 'Am

Di awal QS. Maryam ayat 33 terdapat lafadz "Salam" yang meupakan kata mufrod diikuti dengan "Al Istighra Qiyyah $\mathrm{Li} \mathrm{Al}$ Jinsi”, yang menyebabkan lafadz tersebut menjadi Definite/Makrifah, atau biasa disebut dengan lafadz "Am". ${ }^{29}$ Sehingga dengan itu

\footnotetext{
${ }^{27}$ Al-Qur an, (Al-Mumtahanah: 60), 8.

${ }^{28}$ Dalil Dan Argumen Mengucapkan Selamat Natal Menurut Para Ulama' Dunia, dalam https://dutaislam.com/artikel/Fikih/Litera (25 Desember 2017)

${ }^{29}$ Abdul Wahhab Khallaf, “Ilmu Ushul Fikih”, (Semarang: Dina Utama, 2014), Cet.02, 332.
} 
menurut beliau Nabi Isa As memohon segala macam salam agar tercurahkan kepadanya. dan masuk dalam kategori tersebut menurut beliau adalah ucapan "Selamat Natal". sehingga menurut M. Quraish Shihab ayat tersebut merupakan ayat pertama yang merestui ucapan "Selamat Natal". ${ }^{30}$ inilah yang membedakan M.Quraish Shihab dengan ulama' yang lain. Ulama' yang lain membolehkan ucapan Selamat Natal dengan beralasan "Mujamalah Dan Muhasanah" tanpa mengatakan hal sebagaimana yang diutarakan M. Quraish Shihab.

Secara logika, jika memang Nabi IsaAs merestui ucapan Selamat Natal berarti secara tidak langsung Nabi Isa As merespon positif terhadap perilaku umat Nasrani yang menganggap dirinya sebagai Tuhan. Sebagaimana yang dijelaskan di muka, bahwa walaupun Isa Al-Masih tidak diketahui dengan pasti dilahirkan kapan. Namun umat nasrani menetapkan "Natal" dengan menggunakan beberapa metode. Dan secara tradisi perayaan hal itu sebelumnya juga merupakan perayaan umat penyembah matahari di Babilonia. ${ }^{31}$ yang hal tersebut juga bertentangan dengan ajaran Islam.

Sedangkan dalam Al-Qur an sendiri dijelaskan bahwa Isa As diutus sebagai nabi pada umatnya, sebagaimana firman Allah SWT:

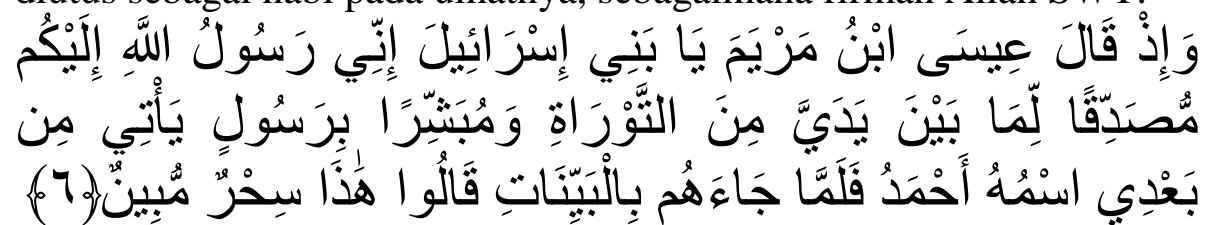

"Dan (ingatlah) ketika 'Isa ibnu Maryam berkata: "Hai Bani Israil, sesungguhnya aku adalah utusan Allah kepadamu, membenarkan kitab sebelumku, yaitu Taurat, dan memberi khabar gembira dengan (datangnya) seorang Rasul yang akan datang sesudahku, yang namanya Ahmad (Muhammad)." Maka tatkala rasul itu datang kepada mereka dengan membawa bukti-bukti yang nyata, mereka berkata: "Ini adalah sihir yang nyata."

Dalam ayat tersebut terdapat lafadz عيسى ابن مريم menurut ibnu خاتم الانبياء من بني إسرائيل katsir yang dimaksud lafadz tersebut adalah yang dari penafsiran tersebut dikatakan bahwa Isa As adalah seorang nabi yang berasal dari bani Israil. ${ }^{32}$ Sedangkan dalam tafsir AlMaraghi dijelaskan bahwa ayat tersebut merupakan perkataan sekaligus pengakuan atas kenabian Nabi Isa As kepada kaumnya yang

${ }^{30}$ M. Quraish Shihab, “Tafsir Al-Misbah...........180

${ }^{31}$ Herbert W. Amstrong, “Asal-Usul Perayaan Natal............... 10

${ }^{32}$ Imam Al-Jalil 'Amad Al-din Abi Al-FidaI Isma'il,.................Jld: 13, 545. 
dibenarkan dengan kitab taurat dan kitab-kitab Allah yang lain dan oleh nabi-nabi Allah sebelum dan sesudah terutusnya Nabi Isa As. ${ }^{33}$ Dan masih ada beberapa ayat Al-Qur an yang menjelaskan kenabian Nabi Isa As.

Alasan inilah yang sungguh tidak masuk akal ketika mengatakan bahwa Nabi Isa As merestui ucapan "Selamat Natal".

b. Syaddud Dzari'ah

Saddud Dzari'ah adalah menutup jalan terjadinya kerusakan. ${ }^{34}$ Salah satu alasan M. Qurash Shihab dalam menetapkan hukum mengucapkan selamat natal tidak lain untuk menjaga keharmonisan dan kerukunan antar umat beragama. Salah satu jalan untuk menempuh hal tersebut yaitu dengan menghargai hari keagamaan mereka. terutama di era sekarang, dimana islam dipandang dengan kacamata merah oleh mereka yang Non-Muslim dengan sebutan Islam Radikal dan Islam Teroris atau semacamnya.

c. Kaidah Fikih "Maqashidul Lafdzi 'Ala Niatil Lafidzi"

Apa yang diucapkan tergantung niat yang mengucapkan. Seperti yang dijelaskan dimuka, bahwa menurut M. Quraish Shihab pengucapan ucapan "Selamat Natal" tergantung niat individu masingmasing. Walaupun nanti Mukhothob memahaminya sama dengan apa yang ia maksud. Yang mengucapkan dengan niat sopan santun atau mempercayai hari kelahiran Isa As sebagai nabi bukan sebagai Tuhan. Sehingga itu tidak berpengaruh terhadapa akidah seorang muslim.

Interpretasi M. Quraish Shihab Terhadap QS. Maryam: 33.

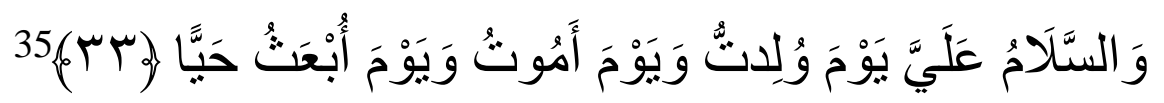
"Dan kesejahteraan semoga dilimpahkan kepadaku, pada hari aku dilahirkan, pada hari aku meninggal dan pada hari aku dibangkitkan hidup kembali"

Menurut salah satu mufassir terkemuka Indonesia ini, ayat tersebut merupakan ayat yang melegalkan ucapan "Selamat Natal". Dalam ayat tersebut terdapat kata "Sala>m" yang menurut beliau kata

\footnotetext{
${ }^{33}$ Ahmad Mustofa Al-Maraghi, "Tafsir Al-Maraghi”, (T.tp: Maktabah Mushtofa AlBabiy Al-Halabiy, 1946, Juz 28), 84.

${ }^{34}$ Amir Syarifuddin, “Ushul Fiqih”, (Jakarta: Kencana, 2008), Jld.02, 448.

${ }^{35}$ Al-Qur an, (Maryam:19), 33.
} 
tersebut samahalnya dengan pernyataan dari Allah SWT tentang tercurahnya "Salam" kepada Nabi Yahya As. Sedangkan pada ayat tersebut merupakan ucapan Nabi Isa As. Disisi lain,, kata "Salam" yang tercurahkan kepada Nabi Yahya AS tersebut berbentuk Isim Nakirah/Indefinite. Sedangkan pada ayat di atas berbentuk Makrifah/Definite., yakni dengan menggunakan Alif dan Lam yang bisa memakrifatkan isim nakirah, dan $\mathrm{Al}$ tersebut juga dinamakan " $\mathrm{Al}$ Istighraqiyah Lil Jinsi" yang dengannya kata "Salam" di atas mencakup segala macam salam dan kedamaian. Dengan demikian menurut Quraish Shihab, Isa As dalam ucapannya ini ia memohon agar segala macam salam dan kedamaian melimpah kepadamya pada ketiga kondisi tersebut, yakni saat dilahirkan, di wafatkan, dan dibangkitkan kembali. ${ }^{36}$ Namun, menurut mufassir yang lain, ayat tersebut merupakan sebuah sketsa/gambaran terhadap kondisi Nabi saat mengalami ketiga masa sulit tersebut, ${ }^{37}$ dan juga merupakan ikrar penghambaan Nabi Isa As sebagai makhluk biasa kepada Allah SWT. ${ }^{38}$

Menurut beliau, ayat tersebut mengabadikan serta merestui ucapan selamat hari kelahiran Isa Al-Masih (Natal) yang diucapkan pertama kali oleh Nabi Isa As. Sehingga tidak ada larangan untuk mengucapkan "Selamat Natal". Karena menurut beliau, mayoritas ulama yang melarang ucapan tersebut dikarenakan mengaitkan ucapan tersebut dengan makna populernya, yakni ketuhanan tentang Yesus Kristus. Makna ini jelas bertentangan dengan akidah Islamiah, sehingga ucapan Selamat Natal paling tidak, dapat menimbulkan kerancuan serta kekaburan akidah. ${ }^{39}$

Beliau juga berpendapat bahwa ucapan selamat atas kelahiran IsaAs (Natal) manusia agung suci itu memang ada dalam Al-Qur an yang kini perayaannya dikaitkan dengan ajaran agama Kristen yang keyakinannya kepada Isa Al-Masih berbeda dengan pandangan umat Islam. Sehingga mengucapkan ucapan Selamat Natal dan menghadiri perayaannya dapat menimbulkan kesalah pahaman yang menyebabkan pengaburan ibadah. Ini dapat dipahami sebagai pengakuan terhadap ketuhanan Isa Al-Masih, satu keyakinan yang secara muthlak bertentangan deng akidah islam. Dan alasan inilah yang melatar

${ }^{36}$ M. Quraish Shihab, “Tafsir Al-Misbah, ............Vol: 08, 180

${ }^{37}$ Abi $>$ Jakfar Muhammad Bin Jarir........juz: 15, 534.

${ }^{38}$ Ahmad Musthofa Al-Maraghi, ..........Juz: 16, 49.

${ }^{39}$ Ibid, 180. 
belakangi haramnya ucapan selamat natal. Bahkan, apapun yang berhubungan dengan perayaan itu tidak dibenarkan.

Beliau berperbendapat bahwasannya mengucapkan "selamat natal" sama halnya kita memohonkan curahan sholawat dan salam untuk Nabi IsaAs. Sebagaimana kita memohonkan untuk nabi dan rasul. Merayakan hari Natal/hari lahir Nabi IsaAs samahalnya dengan merayakan keselamatan nabi Musa As dari gangguan Fir'aun yang hal tersebut ditandai dengan berpuasa Asyura. Beliau juga berkata yang didasarkan pada hadits Nabi, bahwasanya para Nabi bersaudara hanya ibunya saja yang berbeda, seluruh umatpun juga bersaudara, sehingga tidak ada salahnya kita bergembira dam menyambut kegembiraan saudara kita dalam batas kemampuan kita dan batas yang digariskan oleh anutan kita. ${ }^{40}$ Bahkan, hal tersebut tidak hanya diperbolehkan namun lebih dari itu, karena pada prinsipnya dalam sebuah agama orang disekitar kita hanya satu dari dua yakni bisa saja seagama, bisa saja beda agama. Namun walalu demikian orang tersebut pasti sekemanusiaan dengan kita. Dan Nabi IsaAs hadir dengan membawa ajaran dari sumber yang sama dimana Nabi Muahammad menerimanya, dengan membawa kasih dan perdamaian. ${ }^{41}$ Dengan demikian, mengucapkan "Selamat Natal" tidak ada larangan di dalamnya selama akidah masih dapat dipelihara, dan selama ucapan itu sejalan dengan yang dimaksudkan Al-Qur an sendiri yang telah mengabadikan ucapan Selamat Natal. Hal tersebut alasan yang membenarkan umat muslim mengucapkan selamat atau menghadiri upacara Natal yang bukan ritual. ${ }^{42}$ dan ucapan selamat natal yang diucapkan seorang muslim tidak lain hanya sebatas basa basi dalam konteks kehidupan dan kerukunan. ${ }^{43}$

Pada dasarnya, larangan yang muncul dalam permasalahan ini dalam rangka upaya memelihara akidah, karena kekhawatiran kerancuan pemahaman, karena itu agaknya larangan tersebut lebih banyak ditujukan kepada mereka yang dikhawatirkan kabur akidahnya. Sehingga, jika demikian, apabila saat ketika

\footnotetext{
${ }^{40}$ Ibid, 182.

41 M. Quraish Shihab, "Hukum Mengucapkan Natal", dalam https://servicesdirectory.withyoutube.com/directory/pt-digital-rantai-maya/video yang diunggah pada 24 desember 2018.

${ }_{42}$ M. quraish shihab, "Membumikan............, 583.

43 M. Quraish Shihab, "Hukum Mengucapkan Natal”, dalam https://servicesdirectory.withyoutube.com/directory/pt-digital-rantai-maya/video yang diunggah pada 24 desember 2018.
} 
mengucapkannya akidah seseorang tetap murni, yakni mengucapkannya sesuai dengan kandungan "Selamat Natal Qur a>ni", yang kemudian mempertimbangkan kondisi dan situasi orang yang mengucapkan, sehingga tidak menimbulkan kerancuan akidah bagi dirinya dan juga muslim yang lainnya. ${ }^{44}$

Dalam interaksi sosial dan keharmonisan hubungan, Al-Qur an dan Hadits memperkenalkan satu bentuk redaksi, dimana lawan bicara memahaminya sesuai dengan persepsinya tetapi tidak dengan yang dimaksud pengucapnya, karena si pengucap sendiri mengucapkan dan memahami redaksi itu sesuai dengan pandangan dan persepsinya pula. $^{45}$

Sahabat Nabi SAW, Anas Ibnu Malik RA, menyampaikan bahwa suatu ketika sahabat Nabi SAW bernama Abu Thalhah, harus bepergian saat anaknya sedang sakit. Beberapa saat setelah kepergiannya, sang anak meninggal dunia. Ketika Abu Thalhah kembali, ia bertanya kepada istrinya tentang keadaan sang anak. Istrinya (yang rupanya enggan mengejutkan suaminya dengan berita sedih tersebut), menjawab: (هو اسكن ماكان)"dia dalam keadaan yang setenang-tenangnya". Tenteram hati suami mendengarnya, karena menduga bahwa anaknya sedang tidur nyenyak, padahal ketenangan yang dimaksud sang ibu, adalah kematian. Ketika Abu Thalhah mengetahui hal yang sebenarnya ia mengadukan istrinya kepada Nabi Muhammad SAW. Beliau bertanya:"apakah semalam kalian melakukan hubungan suami istri?" pertanyaan ini diiyakan oleh Abu Thalhah, maka Nabi Muhammad SAW mendoakan suami istri itu. Begitulah yang diriwatkan oleh Bukhari dan Muslim. Terlihat disini bagaimana Nabi SAW membenarkan/tidak menegur istri Abu> Thalhah yang menggunakan redaksi yang sengaja ia susun agar ddipahami oleh suaminya berbeda dengan apa yang ia maksud. ${ }^{46}$

Al-Qur a>n juga memperkenalkan yang demikian. Salah satu contoh adalah QS. Saba' (34):25. Disana Rasulullah SAW diperintahkan untuk menyampaikan kepada kaum musyrikin bahwa:

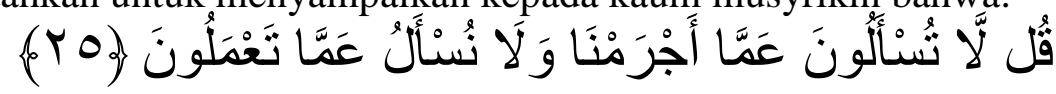

"kami tidak akan diminta mempertanggung jawabkan "dosa besar" yang telah kami perbuat, kami pun tidak mempertanggung jawabkan "apa yang kamu lakukan”.

${ }^{44}$ M. quraish shihab, "Tafsir........183.

${ }^{45}$ Ibid, 583.

${ }^{46}$ M. Quraish Shihab, “Tafsir Al...... 183. 
Dalam redaksi tersebut, "Dosa Besar" dipahami sebagaimana apa adanya oleh lawan bicara, tetapi apa yang dimaksud oleh pembicara adalah kekeliruan- kekliruan kecil, sedang "apa yang kamu lakukan" dipahami juga oleh lawan bicara dengan "dosa-dosa kecil", sedangkan yang dimaksud pembicara adalah kekufuran, kedurhakaan, dan dosa-dosa besar. Demikian pandangan pakar Tafsir AzZamakhsyari dan diakui oleh banyak penafsir. ${ }^{47}$

Dalam ayat tersebut tidak dikatakan "dosa-dosa kamu" tapi dikatatan "apa yang kamu perbuat" hal tersebut disemakkan ketika dikatakan kepada mereka yang Non-Muslim. Hal tersebut untuk menjunjung kedamaian hidup, dan tidak ada yang bisa mempersoalkan hall tersebut hanya Tuhan yang bisa memutuskan mana yang benar mana yang salah. ${ }^{48}$

Dalam konteks ucapan Selamat Natal, kalaupun Non-Muslim memahami ucapan itu sesuai dengan keyakinannya, maka biarlah demikian. Karena sang muslim yang mengucapkannya memahami ucapannya itu sesuai dengan ukuran keyakinannya.

Tidak keliru dalam kacamata ini, fatwa dan larangan mengucapkan Selamat Natal, bila larangan itu ditujukan kepada yang dikhawatirkan ternodai akidahnya, tetapi tidak juga salah yang membolehkannya selama pengucapnya arif bijaksana dan tetap terpelihara akidahnya, lebih-lebih jika hal tersebut merupakan tuntutan keharmonisan sebuah hubungan.

Boleh jadi pendapat ini dapat didukung dengan menganalogikannya dengan pendapat yang dikemukakan oleh beberapa ulama yang menyatakan bahwa seorang nasrani bila menyembelih binatang halal atas nama Al-Masih Putra Maryam, maka sembelihan tersebut boleh dimakan oleh muslim, baik penyebutan tersebut diartikan sebagai permohonan Sholawat dan Salam untuk beliau, atau dengan arti apapun. Demikian dikutip Al-Biqa'i dari kitab Ar-Raudhah, yang beliau cantumkan dalam tafsirnya ketika menjelaskan QS. Al-An'am (6):121. Memang kearifan dibutuhkan dalam interaksi sosial. ${ }^{49}$

\footnotetext{
${ }^{47}$ Ibid, 184

${ }^{48}$ M. Quraish Shihab Bersama Romo Budi, "Muslim Dan Nasrani Bersaudara", dalam https://servicesdirectory.withyoutube.com/directory/pt-digital-rantaimaya/video yang diunggah pada 24 desember 2018.
}

${ }^{49}$ M. Quraish Shihab, “Tafsir Al 184. 


\section{Kritik Terhadap Penafsiran M.Quraish Shihab Tentang Ucapan Selamat Natal}

Berdasarkan penafsiran yang telah dikemukakan sebelumnya, peneliti akan memaparkan maksud dari QS. Maryam 33 yang oleh M. Quraish shihab dijadikan landasan dalam masalah pelegalan ucapan selamat Natal. melihat dari penafsiran di atas baik menurut mufassir klasik sepertihalnya Ibnu Katsi $>r$ maupun mufassir kontemporer sepeti Imam At-Thabari dan semacamnya, ayat tersebut sama sekali tidak membahas masalah natal, namun ayat tersebut merupakan ayat yang berisi 3 konten yang meliputi:

a. Tentang kondisi Nabi Isa As yang lahir dengan selamat di tengah hiruk pikuk keluarga Maryam yang mengusirnya saat hendak melahirkan Isa As serta kondisi Maryam yang begitu sulit saat ada di tengah gurun pasir. Dan juga ibunda Nabi Isa selamat dari godaan setan tatkala mau melahirkan Nabi Isa As. Dari proses adanya Nabi Isa yang dilahirkan, ini membuktikan bahwa Nabi IsaAs adalah seorang manusia biasa yang menghamba kepada Rabb Nya. Sehingga menurut Ibnu Katsir ayat tersebut merupakan ayat yang berisi ikrar penghambaan Nabi IsaAs.

b. Kondisi nabi isa yang selamat dari niat jahat kaumnya untuk menyalib Nabi IsaAs. Saat rencana itu mulai dilaksanakan Allah SWT menggantikannya dengan seseorang yang mirip dengan Nabi IsaAs. Sehingga Nabi Isa As selamat dari kematian yang direncanakan kaumnya tersebut.

c. Kabar bahwasanya Nabi Isa As akan dibangkitkan kembali kelak dihari kiamat setelah dia diangkat ke langit saat hendak disalib kaumnya untuk menyelamatkan manusia dari fitnah dajjal.

Dari ketiga konten isi ayat tersebut tidak ada satupun yang menyinggung Natal. sebab, seperti yang telah peneliti jelaskan di muka bahwa "Natal" adalah perayaan umat Nasrani dalam memperingati kelahiran Isa As atau yang biasa disebut "Yesus" yang dalam kepercayaan mereka, dia diangap sebagai "Tuhan Anak" walaupun kitab suci mereka sendiri tidak merestui perayaan tersebut namun mereka tetap meyakini bahwa perayaan tersebut merupakan perayaan terhadap kelahiran Yesus atau tuhan anak. ${ }^{50}$ Sedangkan ayat tersebut membahas kelahiran Isa As yang statusnya sebagai manusia

${ }^{50}$ Herbet W. Amstrong, “Asal-Usul Perayaan Natal .10 
biasa namun menerima sebuah keistmewaan sebagai nabi dan rasul. Sebagaimana pengakuan Nabi Isa As terhadap kaumnya yang tertera dalam firman Allah SWT:

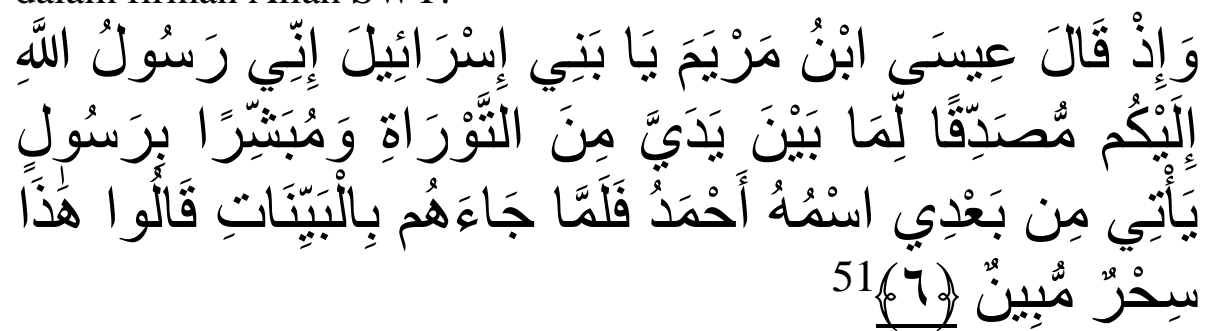

"Dan (ingatlah) ketika 'Isa ibnu Maryam berkata: "Hai Bani Israil, sesungguhnya aku adalah utusan Allah kepadamu, membenarkan kitab sebelumku, yaitu Taurat, dan memberi khabar gembira dengan (datangnya) seorang Rasul yang akan datang sesudahku, yang namanya Ahmad (Muhammad)." Maka tatkala rasul itu datang kepada mereka dengan membawa bukti-bukti yang nyata, mereka berkata: "Ini adalah sihir yang nyata."

Jadi, ayat tersebut sama sekali tidak menjelaskan "Natal" dan hal-hal yang berhubungan dengan Natal sepertihalnya "Ucapan Selamat Natal".

\section{Epilog}

Seperti yang dijelaskan di muka bahwa dalam menetapkan pelegalan ucapan "Selamat Natal" ulama' berbeda pendapat. Ada yang melegalkan adapula yang mengilegalkan. Hal tersebut dikarenakan masalah ini memang masalah khilafiyah. Mereka yang membolehkan ucapan "Selamat Natal" tidak lain hanya dengan maksud "Muhasanah dan Mujamalah" antar umat beragama. Yang penulis rasa hal tersebut dinilai sangat penting ketika seseorang hidup di Negara yang pendudukanya menganut Agama Nasrani dengan populasi yang cukup tinggi. Apalagi di tengah Islam yang dipandang sebelah mata dengan predikat agama radikal dan semacamnya yang sekiranya tidak pantas disandang, mungkin hal tersebut bisa memperbaiki pamor Islam dimata Non-Muslim.

Sedangkan dalam masalah M. Quraish Shihab menggunakan QS. Maryam 33 sebagai salah satu alasan dalam melegalkan ucapan "Selamat Natal". Namun, alasan terbesarnya ia mengatakan bahwa ayat tersebut yang merestui ucapan selamat natal. hal inilah yang

${ }^{51}$ Al-Qur an, (Shaff: 61), 06. 
menjadi sorotan penulis. Dari beberapa literature yang penulis kaji mengenai penafsiran ayat tersebut, tidak ada ulama' yang menyatakan bahwa ayat tersebut merupakan ayat yang pertama kali merestui ucapan Selamat Natal. Ulama'-ulama' yang lain hanya berpendapat bahwa ayat tersebut menggambarkan kondisi Isa As saat dilahirkan, diwagatkan, dan dihidupkan kembali. Dan jikalau ayat tersebut memang merestui ucapan selamat Natal maka secara tidak langsung M. Quraish Shihab mengatakan bahwa Isa As merestui perayaan "Natal" yang secara sejarahpun perayaan itu muncul dari kepercayaan para paganism, sebagaimana dijelaskan sebelumnya. Inilah salah satu dalih M. Quraish Shihab yang mungkin bisa dikatakan bersebrangan dengan pendapat mufassir dan ulama' fikih yang lain. Sedangkan untuk alasan beliau selebihnya sama dengan alasan ulama'-ulama' yang lain dalam melegalkan ucapan "Selamat Natal". walaupun pada dasarnya beliau M. Quraish Shihab mentafshil individu yang diperbolehkan mengucapkan ucapan tersebut dengan menggunakan metode yang terakhir, yakni "Maqashidul Lafdzi 'Ala Niatil Lafidzi".

\section{DAFTAR PUSTAKA}

Agil Husni Al-Munawwar, Said, Fikih Hubungan Antar Agama. Jakarta: Ciputat Press, 2003.

Azra, Azyumardi, Konteks Berteologi Di Indonesia Pengalaman Islam, Jakarta: PARAMADINA, 1999.

Al-Bukhori, Sahih Al-Bukhori,(t.t : Shirkah An-Nur Asia, T. th), juz:2

Amstrong, Herbert W., "Asal-Usul Perayaan Natal”, (Masyhud SM, Penerjemah), t.t: t.p, T.th.

Ahmad, Mirza Tahir, “Ajaran Kristen Dari Kenyataan Ke Khayalan”, (Penerjemah: Ali Tayyibah), Bogor: Jemaat Ahmadiyah Indonesia, 2000).

Amstrong, Karen, "Sejarah Tuhan, Kisah 1000 Tahun Pencrian Tuhan Dalam Agama-Agama Manusia”, Bandung: Mizan, 2018.

Afandi, Sayyid Husain, “Al-Hushunu Al-Hamidiyyah”, Surabaya: AlHidayah, T.Th.

Arabi, Ibnu, "Rahasia Asmaul Husna”, (Zainul Maarif, Penerjemah), Jakarta: Turos Khazanah Pustaka Islam, 2015.

Al-Adnani, Abu Fatiah, "Nabi Isa AS Akan Turun Di Langit Damaskus”, Jawa Tengah: Granada Madiatama, 2014. 
Al-Damsyiqi, Imam Al-Jalil 'Amad Al-din Abi Al-FidaI Isma'il Ibnu Katsir, "Tafsir Al-Qur an Al- 'Adzim”, T.T: T.P, T.Th, juz 13.

Al-Khurasyi, Sulaiman Bin Shalih: Pemikiran Dr. Yusuf Al-Qardhawi Dalam Timbangan, (M. Abdul Ghaffar, Penerjemah), Bogor: Pustaka Imam Syafi'i, 2003.

Abu Ubaidah, Darwis, Panduan Akidah Ahli Sunnah Wal Jamaah, Jakarta Timur: Pustaka Kautsar, 2008.

Al-Maraghi, Ahmad Mustofa, "Tafsir Al-Maraghi", Mesir: Maktabah Mushtofa Al-Babiy Al-Halabiy, 1946.

At-Thabariy, Abi Ja'far Muhammad Ibn Jarir, "Tafsir At-Thabariy Jami'u Al-Bayan Fi Tawili Ayi Al-Qur an”, Mesir: T.P, T.Th.

Al-Malibari, Muhammad Nashir Ahmad As-Syafi'iey, Rad'u AlAghwad 'An Muwalati Al-Kuffari Wa At-Tasyabbuhi Bihim Wa Tahniatihim Bi Al-A'yad, Indonesia: Menara Ahli Sunnah, 2018.

Al-Baghdadiy, Mahmud Al-Alusiy, Ruh Al-Ma'aniy, Beirut, Libanon: Dar Ihya' Al-Turats Al-'Arabiy, T.th.

As-Sya'rowi, Imam Mutawali, "Tafsir As-Sya'ro>wi”, Juz 15, T.t: T.p, T.Th.

As-Syarbini, Imam Khatib, “Mughni Al-Muhtaj”, jld: 06, T.Tp: T.P, T.Th.

Al-Jauzi, Syaikh Muhammad Bin Abi Bakr Ibnu Qoyyim, "Ahkam Ahl Ad-Dzimmah”, jld: 01, Saudi Arabia: Romadi Li An-nasyr, 1997.

An-Nawawiy, Muhyiddin, “Ar-Raudlah”, Jld: 10, T.Tp: T.p, T.Th.

Al-Anshoriy, Syaikhul Islam Zakariya, "Syarh Al-Manhaj”, Jld: 04, Mesir: Mustofa Al-Babi Al-Halabi, 1345.

Al-Bajuriy, Imam Ibrahim, Hasyiah Al-Bajuriy 'ala Syarh Ibnu Qasim Al-Ghazi 'Ala Matni Al-Ghayah, jld: 04, Jeddah: Dar AlMinhaj, 2016.

Al-Hanbali, Syaikh Manshur Bin Yunus Bin Idris Al-Bahutiy, "Kassyafu Al-Qona' 'An Matni Li Al-Iqna' Li Al-Bahutiy”, Riyadh: Dar 'Alam Al-Kutub, 2003.

Blog, The Freethinker, "Asal Usul 25 Desember Sebagai Hari Natal Yesus Kristus", Dalam Https//:Www.Ioanesrakhmat.Blogspot.Com/Kolom, pada Jakarta:01.Desember.2009.

Agama-Agama Di Indonesia, http://ilmupengetahuanumum.com/artikel

Chandra, Tony, "Perbedaan Katolik Dan Protestan", dalam Http;//www.kaskus,co.id/artikel (05 November 2015). 
Djohan, Bang Abdi, "Kisah Kelahiran Nabi Isa Menurut Al-Qur'an" Dalam "Http://Suaraislam.Com/Opini.(25/12/2018).

Data Atatistik, "Indonesia Negara Berpenduduk Muslim Terbesar Di Dunia", Https://data boks.katadata.co.id. /29/10/2018.

"Dalil Dan Argumen Mengucapkan Selamat Natal Menurut Para Ulama' Dunia", dalam https://dutaislam.com/artikel/Fikih/Litera (25 Desember 2017)

El Saha, M. Ishom, Hadi, Saiful, "Sketsa Dalam Al-Qur a $>n$ Tempat, Tokoh, Nama, Dan Istilah Dalam Al-Qur a>n”. Seri 2, Jakarta: Lista Fariska Putra, 2005.

Gusmian, Islah, "khazanah tafsir Indonesia”, Jakarta : teraju, 2002.

Haryono, Yudhie R., Rachmawatie, May, Al-Qur'an Buku Yang Menyesatkan Dan Buku Yang Mencerahkan, Jakarta: Gugus Press 2002.

Ibnu Taimiyah, Syaikh Ahmad Bin Abdul Hali>m Bin Abdus Sala>m, Iqtidha $>$ Al-Shira $>$ tha Al-Mustaqi $>m, \quad$ T.t: Mathba'ah Syarfiyyah, 1907.

Khadzin, "Islam Dan Budaya Local, Belajar Memahami Realitas Agama Dalam Masyarakat”, Yogyakarta: Teras, 2009.

Khallaf, Abdul Wahhab, "Ilmu Ushul Fikih", Cet.02, Semarang: Dina Utama, 2014.

Keputusan Nahdlatul Ulama', Dasar Iman Dan Islam, dalam http://www. Nu. Or. Id.

Muhajir, Afifuddin, "Fikih Tata Negara", Yogyakarta: IRCISoD, 2017.

Munawir Abdul Fatah, Muhammad Adib Bisri, "Kamus Al-Bisri", Yogyakarta:T.P, 1999.

Nasrullah, Nasih, "Beda Syaikh Yusuf Al-Qardhawi, Mesir, Dan Saudi Soal Natal", dalam https://republika.co.id/Berita/Fatwa/Khazanah Islam (25 Desember 2017).

Purtanto, Pius a, al-barry, moh dahlan, kamus ilmiyah populer, Surabaya: Arkola, T.Th.

Pakdenono, "Kebohongan Kristen", dalam http://www.geocities.com/Artikel. pada T.tgl/T.bln/2006.

Rollick, Avid, 10 Agama Yang Paling Banyak Penganutnya Di Dunia, Dalam Http;//Jurnalbumi.Com/12/10/17.

Sarwat, Ahmad,"Hukum Mengucapkan Ucapan Selamat Natal", dalam https://rumahfiqih.com/artikel, 25 Desember 2012. 
Shihab, M. Quraish, Membumikan Al-Qur'an, Bandung: Mizan, 2013.

Shihab, M. Quraish, Wawasan Al-Qur'an, Bandung: Mizan, 2013.

Shihab, M. Quraish, "Wawasan Al-Qur'an : tafsir maudlu'i atas berbagai persoalan umat”, Bandung: Mizan Pustaka, 2007.

Shihab, M. Quraish, "Cahaya, Cinta, Dan Canda M. Quraish Shihab”, Tangerang: Lentera Hati, 2015.

Shihab, M. Quraish, "Agama Yang Saya Anut, Dasar-Dasar Ajaran Islam", Tangerang: Lentera Hati, 2018.

Shihab, M. Quraish, "Membumikan Al-Qur'an: Fungsi Dan Peran Wahyu Dalam Kehidupan Masyarakat", Bandung: mizan pustaka, 2013.

Shihab, M. Quraish, "Tafsir Al-Misbah, Pesan, Kesan, dan Keserasian Al-Qur'an”, Jakarta: Lestera Hati, 2008.

Shihab, M. Quraish, "Hukum Mengucapkan Natal", dalam https://servicesdirectory.withyoutube.com/directory/pt-digitalrantai-maya/video yang diunggah pada 24 desember 2018.

Shihab, M. Quraish Bersama Romo Budi, "Muslim Dan Nasrani Bersaudara”, dalam https://servicesdirectory.withyoutube.com/directory/pt-digitalrantai-maya/video yang diunggah pada 24 desember 2018.

Syarifuddin, Amir, "Ushul Fiqih", Jld.02, Jakarta: Kencana, 2008. 